\title{
MET phosphorylation predicts poor outcome in small cell lung carcinoma and its inhibition blocks HGF-induced effects in MET mutant cell lines
}

\begin{abstract}
E Arriola*, ${ }^{*, 2,10}$, I Cañadas ${ }^{2,10}$, M Arumí-Uría ${ }^{2,3}$, M Dómine ${ }^{4}$, JA Lopez-Vilariño ${ }^{4}$, O Arpí ${ }^{2}$, M Salido ${ }^{2,3,5}$,

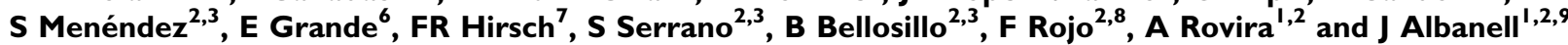

'Oncology Department, Hospital del Mar-Parc de Salut Mar, Passeig Martim 25-29, 08003, Barcelona, Spain; ${ }^{2}$ Cancer Research Program, IMIM-Hospital del Mar, Dr Aiguader, 88, 08003, Barcelona, Spain; ${ }^{3}$ Pathology Department, Hospital del Mar-Parc de Salut Mar, Passeig Maríim 25-29, 08003, Barcelona, Spain; ${ }^{4}$ Oncology Department, IIS-Fundación Jiménez Díaz, Avenida Reyes Católicos 2, 28040, Madrid, Spain; ${ }^{5}$ Department of Health and Experimental Sciences, Universitat Pompeu Fabra, Plaça de la Mercè, 10-12,08002, Barcelona, Spain; ' Oncology Department, Hospital Ramón y Cajal, Madrid, Spain; ' University of Colorado Cancer Center, Aurora, CO, USA; ${ }^{8}$ Pathology Department, IIS-Fundación Jiménez Díaz, Avenida Reyes Católicos 2, 28040, Ctra. de Colmenar Viejo km. 9, 100 28034, Madrid, Spain; ${ }^{9}$ Autonomous University of Barcelona, 08193 Bellaterra, Cerdanyola del Vallès, Spain
\end{abstract}

BACKGROUND: Small cell lung carcinoma (SCLC) has poor prognosis and remains orphan from targeted therapy. MET is activated in several tumour types and may be a promising therapeutic target.

METHODS: To evaluate the role of MET in SCLC, MET gene status and protein expression were evaluated in a panel of SCLC cell lines. The MET inhibitor PHA-665752 was used to study effects of pathway inhibition in basal and hepatocyte growth factor (HGF)stimulated conditions. Immunohistochemistry for MET and p-MET was performed in human SCLC samples and association with outcome was assessed.

RESULTS: In MET mutant SCLC cells, HGF induced MET phosphorylation, increased proliferation, invasiveness and clonogenic growth. PHA-665752 blocked MET phosphorylation and counteracted HGF-induced effects. In clinical samples, total MET and p-MET overexpression were detected in $54 \%$ and $43 \%$ SCLC tumours $(n=77)$, respectively. MET phosphorylation was associated with poor median overall survival ( 32 days) vs $\mathrm{P}-$ MET negative cases $(287$ days $)(P<0.00$ I). Phospho-MET retained its prognostic value in a multivariate analysis.

CONCLUSIONS: MET activation resulted in a more aggressive phenotype in MET mutant SCLC cells and its inhibition by PHA-665752 reversed this phenotype. In patients with SCLC, MET activation was associated with worse prognosis, suggesting a role in the adverse clinical behaviour in this disease.

British Journal of Cancer (20II) I 05, 8I4-823. doi:I0.1038/bjc.201 I.298 www.bjcancer.com

Published online 16 August 201।

(c) 20 I I Cancer Research UK

Keywords: small cell lung cancer; HGF; MET; H69; PHA-665752; mutation

Small cell lung carcinomas (SCLCs) account for $\sim 15 \%$ of lung cancers (Cooper and Spiro, 2006; Govindan et al, 2006). Patients with SCLC show an excellent initial tumour response to chemotherapy, however, the majority have a very poor outcome (Spira and Ettinger, 2004; Cheng et al, 2007).

Several studies on genetic changes and potential molecular targets in SCLC have been performed (Arriola et al, 2008). Disappointingly, however, the standards of treatment and outcome have remained unchanged for the past decade. One of these drugable targets, the MET gene, encodes for a heterodimeric transmembrane receptor tyrosine kinase composed of an extracellular $\alpha$-chain $(50 \mathrm{kDa})$ disulphide bonded to a membranespanning $\beta-(145 \mathrm{kDa})$ chain (Park et al, 1987; Giordano et al,

*Correspondence: Dr E Arriola; E-mail: earriola@hospitaldelmar.cat

${ }^{10}$ These authors contributed equally to this work.

Received 24 May 2011; revised 8 July 2011; accepted 12 July 201 I; published online 16 August 2011
1989). The hepatocyte growth factor (HGF) is the natural ligand of MET (Naldini et al, 1991; Rosen et al, 1994). Upon receptor binding HGF induces phosphorylation of several sites on the juxtamembrane and intracellular domains and mediates, through the interaction with Gab1 (Weidner et al, 1996; Sachs et al, 2000), the activation of several signalling pathways, such as ERK, AKT, PKC $\alpha$ and paxillin FAK (Ponzetto et al, 1994; Furge et al, 2000). This activation results in cellular effects that stimulate invasiveness, tubule formation and branching (Birchmeier et al, 2003).

Activating mutations and $M E T$ gene amplification have been found in lung cancer cell lines and primary tumours, resulting in the constitutive activation of the pathway and its cellular effects in cell line models (Bardelli et al, 1998; Peschard et al, 2001; Ma et al, 2003; Kong-Beltran et al, 2006; Engelman et al, 2007; Lutterbach et al, 2007). Inhibition of MET in these cases has led to inhibition of growth and migration/invasiveness (Christensen et al, 2003; Sattler et al, 2003; Puri et al, 2007; Zou et al, 2007; Corso et al, 2008). Furthermore, a number of studies have assayed the 
expression of MET and, to a lesser extent, p-MET (i.e., activated MET) expression in various human cancers. There are increasingly more consistent data to suggest that total MET and in particular p-MET expression show association with poor survival of cancer patients (Furukawa et al, 1995; Belfiore et al, 1997; Qian et al, 2002; Birchmeier et al, 2003; Puri et al, 2007; Tuynman et al, 2008; Benedettini et al, 2010). In addition, initial results from two phase II studies in patients with advanced NSCLC have recently been reported and demonstrated the therapeutic value of targeting the MET receptor in combination with EGFR tyrosin kinase inhibitors (Schiller et al, 2010; Spigel et al, 2010).

Small cell lung carcinoma is characterized by high invasive and metastatic capacity, a typical feature of MET-activated tumour models (Comoglio and Trusolino, 2002; Danilkovitch-Miagkova and Zbar, 2002) and previous studies suggest a role for MET in SCLC (Maulik et al, 2002; Jagadeeswaran et al, 2007; Ma et al, 2007). However, its relevance for SCLC patient outcome and a potential role of MET inhibitors for the treatment of this disease remain to be determined.

To provide further information on MET as a potential target in SCLC, we studied the effects of a MET inhibitor in a panel of SCLC cell lines and also assayed the expression, activation state and mutational status of MET in a series of human SCLC specimens with complete clinical follow up.

\section{MATERIALS AND METHODS}

\section{Cell lines and reagents}

A panel of 10 SCLC cell lines models was screened for MET alterations for this study. The SCLC cell lines H69, H69AR, H187, SHP-77, H345, H740, H748, H865, and H524 and H1688, and the NSCLC H1993 cells were obtained from the American Type Culture Collection (ATCC) (Rockville, MD, USA). All cells were cultured according to the ATCC instructions (http://www.ATCC.org).

Recombinant human HGF was purchased from Calbiochem (La Jolla, CA, USA) and was resuspended in sterile PBS containing $0.1 \%$ BSA and stored at a stock concentration of $100 \mu \mathrm{g} \mathrm{ml}^{-1}$ at $-80^{\circ} \mathrm{C}$. Treatments (unless otherwise indicated) were done at $40 \mathrm{ng} \mathrm{ml}^{-1}$ as final concentration in culture medium.

PHA-665752, (3Z)-5-[(2,6-dichlorobenzyl)sulfonyl]-3-[(3,5-dimethyl4-1H-pyrrol-2-yl)methylene]-1,3-dihydro-2H-indol-2-one (obtained from Pfizer Inc., San Diego, CA, USA) was dissolved to a stock concentration of $10 \mathrm{~mm}$ in DMSO at $-80^{\circ} \mathrm{C}$. The stock solution was diluted for instant use in our experiments.

\section{Western blot analysis}

The following antibodies were purchased from the manufacturers listed below and used for western blot assay: Met (25H2) mouse monoclonal antibody (mAb), p-MET Y1234/1235 (3D7) rabbit mAb, p-MET Y1349 (130H2) rabbit mAb, p-MET Y1234/35 (D26) $\mathrm{XP}$ rabbit mAb, p-GAB1 Y307-rabbit polyclonal antibody (pAb), ERK1/2 rabbit pAb, p-ERK1/2 (Thr202/Tyr204) pAb were obtained from Cell Signaling (Danvers, MA, USA) and GAB1 (H198) rabbit pAb from Santa Cruz Biotechnology (Santa Cruz, CA, USA). Western blot from whole-cell extracts was performed as previously reported (Codony-Servat et al, 2006).

\section{Fluorescence in situ hybridisation}

The status of the MET gene in cell lines was assessed by fluorescence in situ hybridisation (FISH) using the ON - C-MET (7q31)/SE 7 FISH probes (Kreatech Diagnostics, Amsterdam, The Netherlands), labelling the centromeric alpha-satellite region, specific for chromosome 7 (spectrum green), and the $7 \mathrm{q} 31$ region that contains the MET gene (spectrum orange), as described (Salido et al, 2009).

\section{Mutational analysis of the MET gene by Sanger sequencing}

For mutational studies of tumour samples, DNA was extracted from macrodissected tumoural paraffin-embedded tissue using the QIAamp Tissue Kit (QIAGEN GMBH, Hilden, Germany) according to the manufacturer's protocol. The mutational analysis of the MET gene in cell lines and tumour samples (codons E168, R988 and T1010) was performed by direct sequencing. Primers for PCR amplification and sequencing were designed using the Primer Express software (Applied Biosystems, Foster City, CA, USA) and were as follows: $5^{\prime}$-GCAGCAGCAAAGCCAATTTAT- ${ }^{\prime}$ and $5^{\prime}$-TGA CTTTGGCTCCCAGGGC- $3^{\prime}$ for the E168 and $5^{\prime}$-ACCCATGAGTTC TGGGCACT- $3^{\prime}$ and $5^{\prime}$-CAGAACAATAAACTGAAATATACCTTCT GG-3' for the R988 and T1010. PCR conditions were as follows: $95^{\circ} \mathrm{C} 10 \mathrm{~min} 1 \mathrm{cycle} ; 95^{\circ} \mathrm{C} 1 \mathrm{~min}, 55^{\circ} \mathrm{C}$ for $1 \mathrm{~min}, 72^{\circ} \mathrm{C}$ for $1 \mathrm{~min}, 40$ cycles; and $72^{\circ} \mathrm{C} 10 \mathrm{~min}, 1$ cycle. Sequencing was performed with BigDye v3.1 (Applied Biosystems) following the manufacturer's instructions and analysed on a 3500Dx Genetic Analyzer (Applied Biosystems).

\section{Viability assays}

To measure effects of HGF, PHA-665752 or the combination on the viability of SCLC cell lines, we seeded $3 \times 10^{5}$ cells per well in a sixwell plate with culture medium containing $10 \%$ FBS. After $24 \mathrm{~h}$ HGF, PHA- 665752 or the combination were added at $40 \mathrm{ng} \mathrm{ml}^{-1}$ or $0.5 \mu \mathrm{M}$, respectively, and incubated during $72 \mathrm{~h}$. Cell viability was determined by trypan blue/haemocytometer exclusion method. Each experimental condition was done in duplicate. The results were plotted as percentage of control.

\section{Soft-agar colony formation assay}

Single cell suspensions $\left(2 \times 10^{4}\right.$ cells in $35 \mathrm{~mm}$ plates $)$ were grown in $0.3 \%$ agar containing FBS $10 \%$ in RPMI 1640 medium in the presence and absence of HGF $\left(40 \mathrm{ng} \mathrm{ml}^{-1}\right)$ and PHA-665752 $(0.5 \mu \mathrm{M})$ on top of $0.5 \%$ agar. The plates were incubated $\left(37^{\circ} \mathrm{C}\right.$, $5 \% \mathrm{CO} 2$ ) and cells were fed every 3 days with $0.5 \mathrm{ml}$ of culture medium containing the above-mentioned HGF and PHA-665752 concentrations. The number and size of colonies were evaluated at $\times 20$ magnification on a light microscope at each condition after 21 days.

\section{Invasion assay}

To evaluate the invasiveness of SCLC cell lines we prepared cell suspensions in serum-free media and $2.5 \times 10^{4}$ adherent cells or $1 \times 10^{6}$ cells growing in suspension were seeded into the inserts of 24 -well ( $8 \mu \mathrm{m}$ pore size) CHEMICON Invasion Chamber (CHEMICON International, Inc., Temecula, CA, USA) and treated with PHA-665752 $(0.5 \mu \mathrm{M})$, a concentration that does not have a significant effect on cell viability. Inserts were placed into Falcon companion plates (BD, San Jose, CA, USA) containing 10\% FBS and $40 \mathrm{ng} \mathrm{ml}^{-1} \mathrm{HGF}$ and incubated for $24 \mathrm{~h}$ at $37^{\circ} \mathrm{C}$ and $5 \% \mathrm{CO}_{2}$ atmosphere.

Following incubation non-invading cells were removed from the top chamber using cotton swabs and the outside of the insert was gently rinsed with PBS, stained with $0.25 \%$ crystal violet for $20 \mathrm{~min}$ and rinsed again. Acetic acid (10\%, $200 \mu \mathrm{l}$ per well) was applied to dissolve the stained cells, and then the dye/solute mixture was transferred to a 96-well plate for colorimetric reading of optical density (OD) at $560 \mathrm{~nm}$. The OD value represents the invasive ability. All experiments were performed in triplicate.

\section{Tumour samples and immunohistochemistry}

The following antibodies were used for immunohistochemical studies and purchased from the manufactures listed below: MET 
(3D4) mouse mAb (Invitrogen, San Francisco, CA, USA), MET (SP44) mouse mAb (Ventana-Roche, Tucson, AZ, USA), p-MET Y1349 (130H2) rabbit mAb, p-MET Y1234/35 (3D7) rabbit mAb, p-MET Y1234/35 (D26) XP rabbit mAb (Cell Signaling) (Benedettini et al, 2010) and RON $\beta$ rabbit pAb (C-20) (Santa Cruz Biotechnology). We performed two series of experiments to rule out unspecific staining both in cell lines and tumour samples. First, in both formalin-fixed basal and HGF-treated H69 cell pellets (Supplementary Figure 1), and in human SCLC specimens (Figure 3B), two different anti-MET (3D4 and SP44) antibodies and two anti-p-MET $(130 \mathrm{H} 2$ and D26) resulted in similar staining patterns in 20 (archival SCLC samples) and 30 specimens (from the current series), respectively. Furthermore, sections from same specimens above were incubated with normal mouse IgG2 (X0943, Dako, Carpinteria, CA, USA) or normal rabbit Ig fraction (X0903, Dako) instead of primary antibodies as negative controls. Second, to rule out potential cross-reactivity with RON (Gaudino et al, 1994), we assayed RON, MET and p-MET in a subset of 20 (archival SCLC) tumour specimens by IHC. Specimens RON positive and MET/p-MET negative, and vice versa, were observed (data not shown), thus indicating lack of cross-reactivity in our assays.

The study population consisted of 77 patients diagnosed with SCLC at any stage from whom we had clinical and follow-up information. Biopsies were obtained before treatment and subsequently patients initiated standard chemotherapy regimes. All samples except for two were non-surgical core biopsies as surgery is not a standard procedure in SCLC treatment (usually diagnosed in advanced stages). Specimens were retrospectively retrieved from Parc de Salut Mar Biobank (MARBiobanc, Barcelona, Spain) and Fundación Jiménez Díaz Biobank (Madrid, Spain). This study was approved by the institutional review board of each participating centre. Three- $\mu \mathrm{m}$ tissue sections from formalin-fixed and paraffinembedded samples were obtained, mounted onto charged slides and then, deparaffinised in xylene and hydrated. After heat antigen retrieval performed at high $\mathrm{pH}$ solution using PT Link platform (Dako), slides were incubated with primary antibody for $1 \mathrm{~h}$ at a dilution of $1: 50$ for 3D4 MET, 1:1 MET SP44 mouse mAb, 1:20 for p-MET Y1349 and 1:50 for p-MET Y1234/35. Then, sections were incubated with the specific polymer EnVision Flex + (Dako), revealed with $3-3^{\prime}$ diaminobenzidine, a chromogen, and counterstained with haematoxylin.

Sections were evaluated by two pathologists independently blinded to clinical information on a light microscope (Olympus DX50, Olympus Corp., Tokyo, Japan). The MET and p-MET staining was scored when any percentage of tumour cells was stained in the membrane. A semiquantitative histoscore (Hscore) was calculated, determined by estimation of the percentage of tumour cells positively stained with low, medium, or high staining intensity for each marker. The final score was determined after applying a weighting factor to each estimate. The formula used was Hscore $=($ low $\%) \times 1+($ medium $\%) \times 2+($ high $\%) \times 3$, and the results ranged from 0 to 300 . Staining of non-tumour epithelial cells (normal and metaplastic respiratory bronchial epithelium) was also assessed.

\section{Statistical analysis}

Statistical analysis was carried out with SPSS version 13.0 (SPSS, Inc., Chicago, IL, USA). To analyse correlations between MET status and clinical-pathological variables we used the $\chi^{2}$-test (Fisher's exact test). Correlations between expression scores by different primary antibodies were calculated by Spearman rho test. Overall survival was analysed by the Kaplan-Meier method. Curves were compared by the log-rank test. Multivariate analysis was performed using the Cox proportional hazards model, including the variables that had reached statistical significance in the univariate analysis. All the statistical tests were conducted at the two-sided 0.05 level of significance. Receiver operating curve
(ROC) was used to determine the optimal cutoff point for MET and p-MET overexpression (Baker, 2003). As shown in Results, the cutoff was set for a MET score of 120 and a p-MET Hscore of 5. Specimens with values above these cutoff points were considered as MET or p-MET positive and specimens with values equal or below as negative. Data and statistical analysis reporting are fully compliant with the REMARK guidelines (McShane et al, 2005).

\section{RESULTS}

\section{PHA-665752 inhibits HGF-induced phosphorylation of MET, downstream molecules and HGF-induced proliferation}

To characterize MET status in our cell lines, we performed FISH to study the gene copy number, sequencing to study the mutations described on exon 14 for SCLC and protein expression by western blot. None of the 10 SCLC cell lines showed MET amplification. We found MET amplification in the NSCLC H1993 cell line as previously reported (data not shown). We therefore used this cell line as a positive control of MET activation. In both H69 and H69AR (chemoresistant) we confirmed the reported juxtamembrane mutation $\mathrm{R} 988 \mathrm{C}$ on exon 14 of the MET gene (data not shown) (Ma et al, 2003; Jagadeeswaran et al, 2007). None of the remaining eight SCLC cell lines had R988C or T1010I MET mutations on exon 14. We observed total MET expression by WB in H69, H69AR, H187 and H345 SCLC cells. The H865 cell line presented lower levels of MET expression and the remaining cell lines (H524, SHP-77, H748 and UMC-19) showed lack of MET expression. Based on these results we selected H69 as a MET mutant model and H524 (no expression of MET), H187 (MET expression) and H345 (MET expression) as models of wild-type MET cell lines. Results with H69 were confirmed with H69AR (chemoresistant isogenic cell line also harbouring the R988C mutation).

To further characterize the MET pathway in these selected cells, we performed a western blot analysis of total and phosphorylated MET, and downstream relevant molecules, ERK and GAB-1. As expected, our positive control, the MET amplified H1993 cell line, showed high levels of basal and phosphorylated MET and absence of modulation by HGF $40 \mathrm{ng} \mathrm{ml}^{-1}$. Figure 1 illustrates the basal and HGF-stimulated expression of these markers in SCLC cells. Basal expression of total MET was detected in H69, H187 and H345 but not in the H524 line. Two bands of 170 and $145 \mathrm{kDa}$ were observed corresponding to the unprocessed and mature proteins, respectively. Phosphorylated MET levels were undetectable in $\mathrm{H} 69$, H187, H345 and H524 at basal conditions. When stimulated by HGF (15'), p-MET was upregulated in the H69 and H187 cells, and slightly for $\mathrm{H} 345$; remaining unchanged for H524. We observed induction of phosphorylation of ERK and GAB-1 with the addition of HGF in H69, H187 and H345 cells. PHA-665752 was able to inhibit MET and phosphorylation of downstream molecules in a dose-dependent manner in H69, H187, H345 and H1993 (Figure 1), obtaining a complete inhibition at $0.5 \mu \mathrm{M}$ (data not shown).

We then assayed the effects of HGF and PHA-665752 or the combination on cell viability in selected cell lines. PHA-665752 treatment inhibited growth in the H1993 MET amplified cell line. There was increased proliferation upon HGF treatment in both mutant H69 and H69AR cell lines (30-60\% increase) and this effect was prevented by PHA- 665752 at $0.5 \mu \mathrm{M}$. Neither the proliferative effect nor the inhibitory effects were observed in the MET wild-type H524, H345 and H187 cell lines (Figure 2A).

\section{PHA-665752 inhibits colony formation and invasiveness in MET mutant SCLC cells}

Exposure of $\mathrm{H} 69$ to HGF ( $40 \mathrm{ng} \mathrm{ml}^{-1}$ ) doubled colony formation in soft agar. Consistent with the observation that $\mathrm{H} 69$ is dependent 


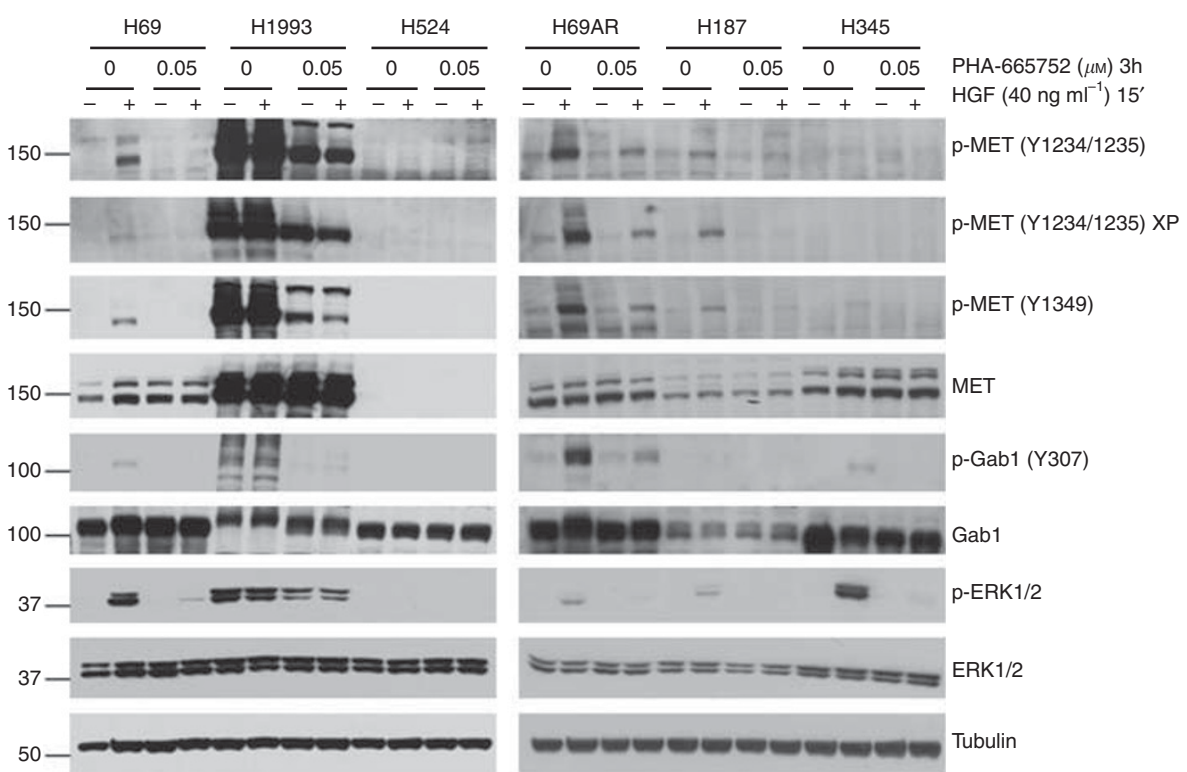

Figure I Hepatocyte growth factor activates MET and downstream molecules in mutant SCLC cell line and PHA-665752 inhibits these effects. Cells were serum starved for $24 \mathrm{~h}$ and then treated with PHA-665752 $(0.05 \mu \mathrm{M})$ for $3 \mathrm{~h}$ and stimulated with HGF $(40 \mathrm{ng} / \mathrm{ml})$ during I5'. Whole cell lysates were purified, size separated by SDS-PAGE, transferred to a membrane and probed with various antibodies.
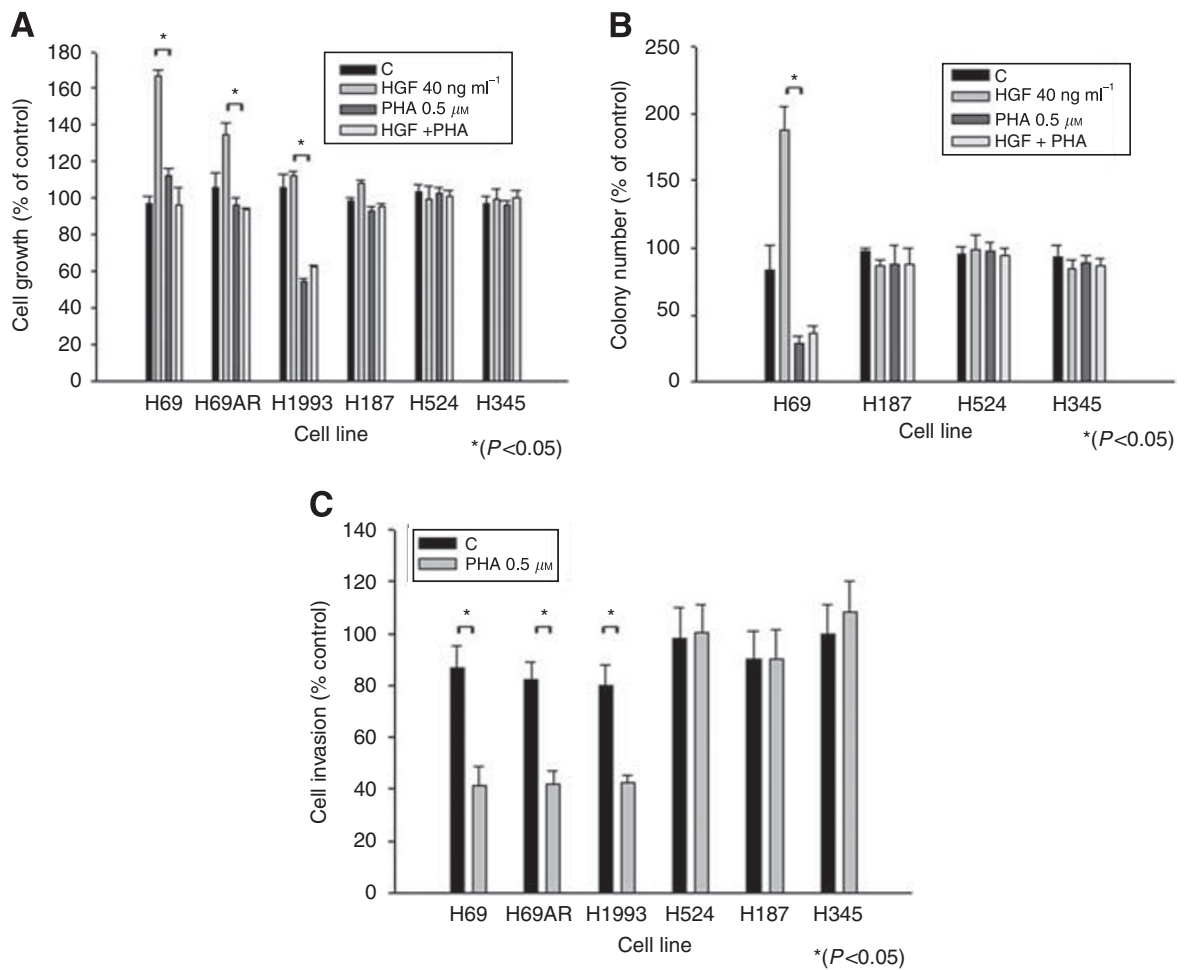

Figure 2 PHA-665752 inhibits HGF-induced cellular effects in MET mutant SCLC cells. (A) The PHA-665752 inhibits HGF-induced cell proliferation in MET mutant SCLC cells. WT and MET mutant cells were treated for $72 \mathrm{~h}$ with HGF. PHA-665752 or HGF + PHA-665752. Cell number was assessed by the trypan blue exclusion method. (B) The PHA-665752 inhibits HGF-induced colony formation in MET mutant SCLC cells. The SCLC cells were cultured in medium containing 0.3\% agar (as described in Material and Methods) in the presence of HGF and PHA for 2 I days. (C) The PHA-665752 decreases cell invasion in MET mutant SCLC cells. Cells were grown in serum-free media and seeded into the inserts of 24-well (8 $\mu \mathrm{m}$ pore size) CHEMICON Invasion Chamber in the presence of PHA-665752 (0.5 $\mu \mathrm{M})$. Inserts were placed into Falcon companion plates containing I0\% FBS and $40 \mathrm{ng} \mathrm{ml}^{-1} \mathrm{HGF}$ and incubated for $24 \mathrm{~h}$. The number of invading cells on the underside of the membrane was determined using crystal violet staining.

on MET signalling, PHA-665752 at $0.5 \mu \mathrm{M}$ reduced colony formation in $\mathrm{H} 69$ cells (Figure $2 \mathrm{~B}$ ), both in non-stimulated and HGF-stimulated conditions $(P<0.05)$. This effect was also observed in H69AR and correlated with inhibition of MET phosphorylation (data not shown). In contrast, these effects were not observed in the H187, H345 and H524 wild-type cell line (Figure 2B). These experiments are consistent with the inhibition of clonogenic growth as associated with inhibition of the MET phosphorylation in MET mutant cell lines but not in wild-type cells. 
A

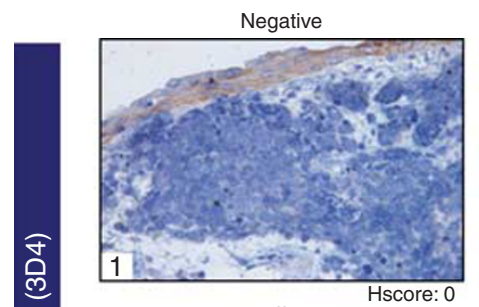

Intermediate diffuse expression
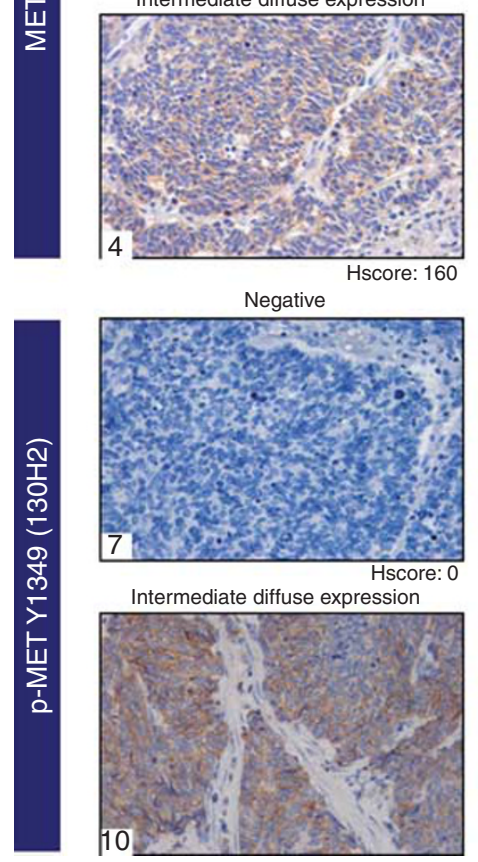

Intermediate diffuse expression

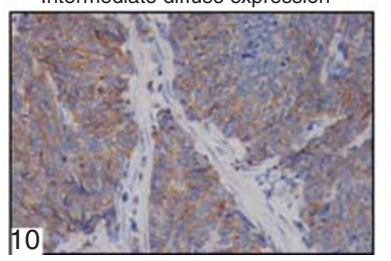

Hscore: 112

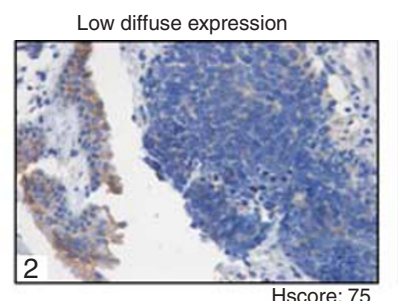

Strong heterogeneous expression
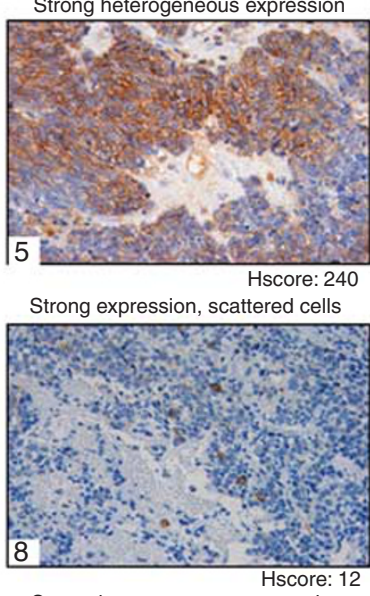

Strong heterogeneous expression

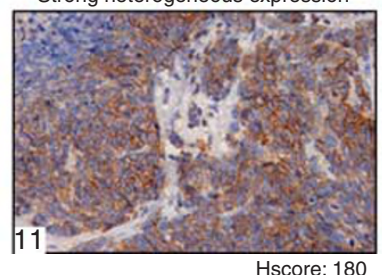

Low diffuse expression

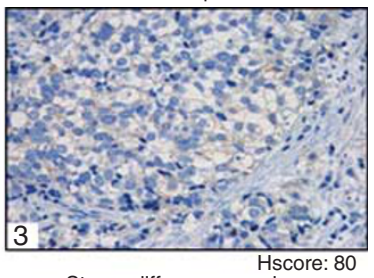

Strong diffuse expression

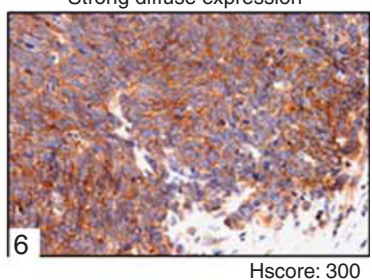

Strong expression, focal

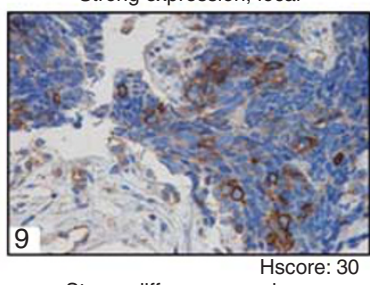

Strong diffuse expression

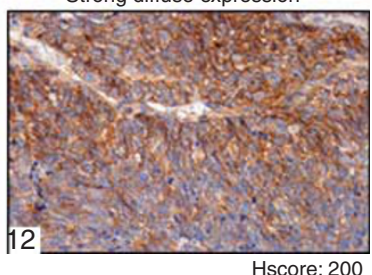

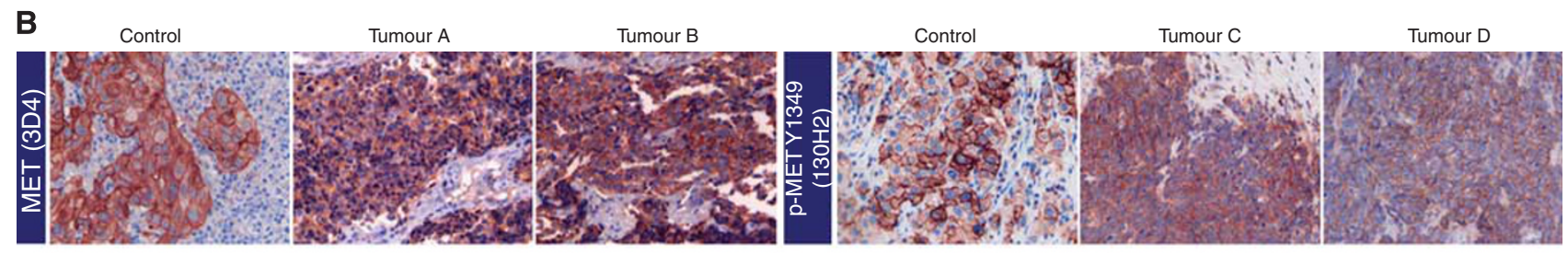
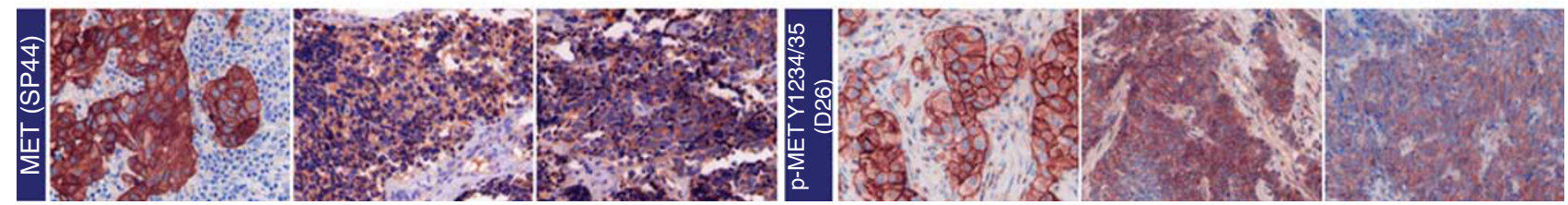

Figure 3 (A) MET and p-MET expression patterns in SCLC. ( I-6) Different patterns of total MET expression in human SCLC (normal epithelia and tumour), assayed by immunohistochemistry. (7-12) Different patterns of p-MET (YI349) expression in human SCLC. Negative expression observed in tumour 7. Strong expression of p-MET in scattered cells (tumour 8), focal (tumour 9) or diffuse (tumour 12). Intermediate or combined strong and intermediate expression patterns were observed in tumours 10 and $1 \mathrm{I}$, respectively. Diffuse: staining of a majority or all tumour cells; heterogeneous: presence of positive tumour areas while others negative. (B) Immunohistochemistry for MET and P-MET in consecutive tissue sections from FFPE lung cancer specimens. A NSCLC (control) sample with well-known levels of MET and p-MET was used in 3D4 and SP44 (MET) and I30H2 and D26 (p-MET) assays. In SCLC samples, same intensity and pattern of staining were observed for MET expression (tumours A and B) and for P-MET (tumours C and D).

To analyse the effect of MET inhibition on invasive capacity of SCLC cell lines we then performed a CHEMICON cell invasion assay. We used HGF as a chemoattractant into the well containing culture medium. Treatment with PHA-665752 $0.5 \mu \mathrm{m}$ decreased invasion of $\mathrm{H} 69$ by $52 \%, \mathrm{H} 69 \mathrm{AR}$ by $50 \%$ and $\mathrm{H} 1993$ by $47 \%$ $(P<0.05)$. In contrast, for the MET wild-type H187, H345 and H524 invasion was not influenced by treatment with PHA-665752 (Figure 2C). These results support a role for MET inhibition in abrogating MET-dependent cells' invasive capacity.

\section{MET and p-MET expression show different patterns in human SCLC}

As MET phosphorylation seems to be a good indicator of the activation of the MET pathway, we explored the implication of the expression of this marker in tumour samples. We sought to evaluate the pattern and prevalence of total MET and p-MET expression in a series of 77 human SCLC samples. The vast majority of the assayed specimens were from primary tumours 
$(n=72)$. Four were from regional lymph nodes and one from a distant site. Patients' characteristics are listed in Table 1.

The MET expression in SCLC samples was consistent using two different primary antibodies (3D4 and SP44) $\left(P=0.009, R^{2}=0.85\right)$.

Table I Clinical characteristics of small cell lung cancer patients

\begin{tabular}{lc}
\hline Patients' characteristics & Number \\
\hline Median age (range) & $65(41-85)$ \\
Gender & \\
$\quad$ Female & $9(12 \%)$ \\
Male & $68(88 \%)$ \\
& \\
Smoking history & \\
Never & $1(1 \%)$ \\
Former & $22(29 \%)$ \\
Current & $54(70 \%)$ \\
Performance status & \\
$0-1$ & $48(62 \%)$ \\
$2-3$ & $13(17 \%)$ \\
Unknown & $16(21 \%)$ \\
Clinical stage & \\
Limited & $32(42 \%)$ \\
Extensive & $42(54 \%)$ \\
Unknown & $3(4 \%)$ \\
\hline
\end{tabular}

The MET phosphorylation was assessed using two antibodies: Y1349 (docking site of MET) and Y1234/35 (autophosphorylation site of MET). Results in Supplementary Figure 2 show a high correlation $\left(P<0.001, R^{2}=0.73\right)$ between both antibodies. Strong agreement was detected in MET and p-MET scores between two observers (MET $P<0.001, R^{2}=0.852$ and p-MET $P=0.001, R^{2}=0.642$ ) and mean of values were considered for statistical analysis. The ROC was used to determine the optimal cutoff points for MET and p-MET overexpression, which were calculated at Hscore of 120 and Hscore of 5, respectively. At this value, the sensitivity of the test for MET was $57.1 \%$, with a specificity of $62.7 \%$, and the sensitivity for p-MET was $46.3 \%$, with a specificity of $85.7 \%$ (Figure 4 ).

A total of $58(75.3 \%)$ specimens showed any grade of MET expression and $42(54.5 \%)$ were considered as tumours with MET overexpression. The MET staining was consistently observed in the membrane of tumour cells, and the expression was diffuse in the tumour. Differences in intensity of MET expression were occasionally detected in the same tumour.

Thirty-three $(42.9 \%)$ cases showed p-MET overexpression following the ROC criteria. All p-MET positive cases expressed the total form of the receptor. The pattern of p-MET staining was membranous and varied from a few cells showing positivity to diffuse staining in other tumours (Figure 3A).

Sixty-eight cases had also histologically normal bronchial epithelium representation in the section. Total MET staining was faintly detected in non-tumour epithelial cells in 67 (98\%) specimens and p-MET staining in 16 (24\%) (Figure $3 \mathrm{~A})$.
A

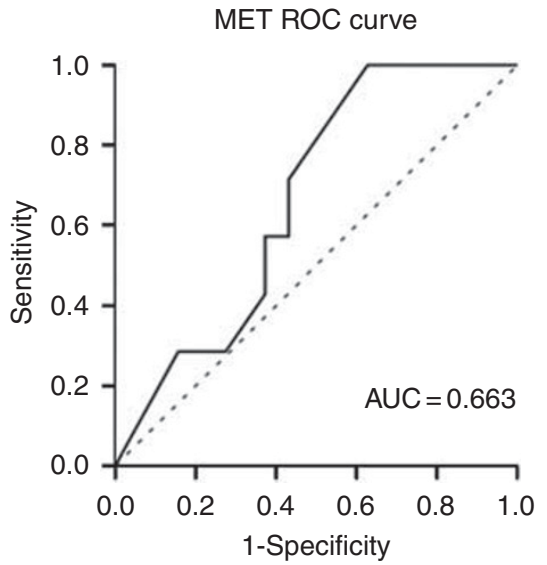

C

MET overall survival

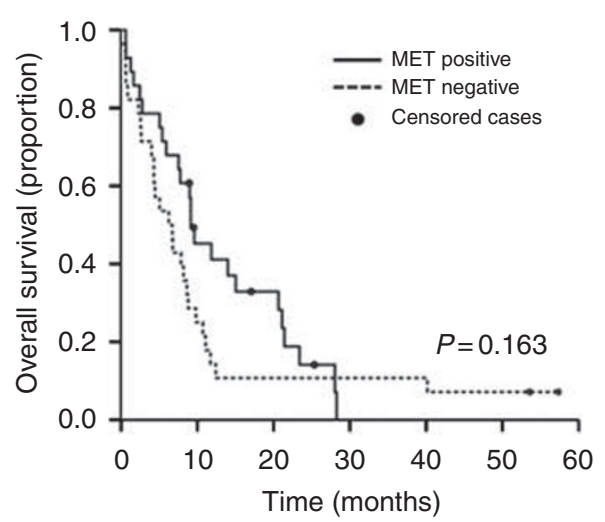

B

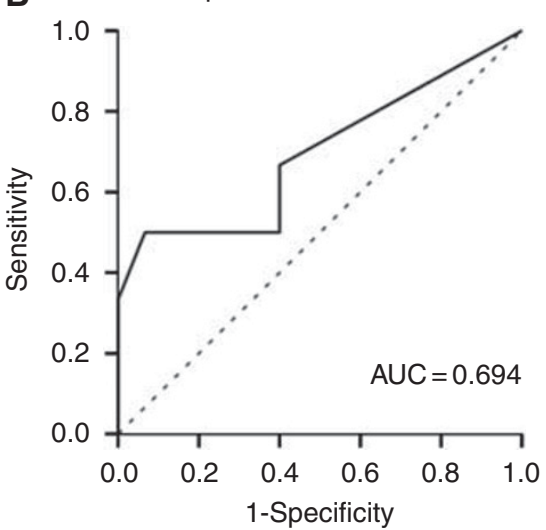

D

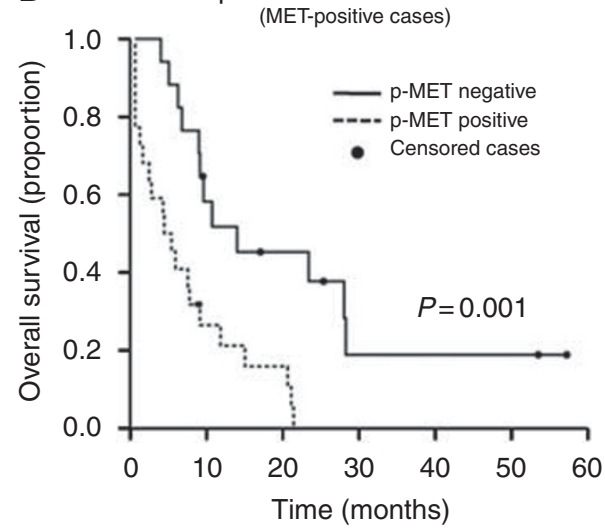

Figure 4 MET and P-MET overexpression threshold and prognostic significance in the cohort of SCLC patients. (A, B) The ROC was used to determine the optimal cutoff point for MET and p-MET expression. The MET and p-MET thresholds according to ROC data were 120 and 5, respectively. At these Hscore values, the sensitivity of the MET test was $57.1 \%$, with a specificity of $62.7 \%$ for MET; and the sensitivity of p-MET assay was $46.3 \%$, with a specificity of $85.7 \%$. These scores were used to define overexpression. (C) Association between MET expression and overall survival. (D) Association between p-MET expression and overall survival. P-values were calculated using the log-rank test and survival curves by Kaplan-Meier analysis. 
Table 2 Association between MET and P-MET expression and clinical variables

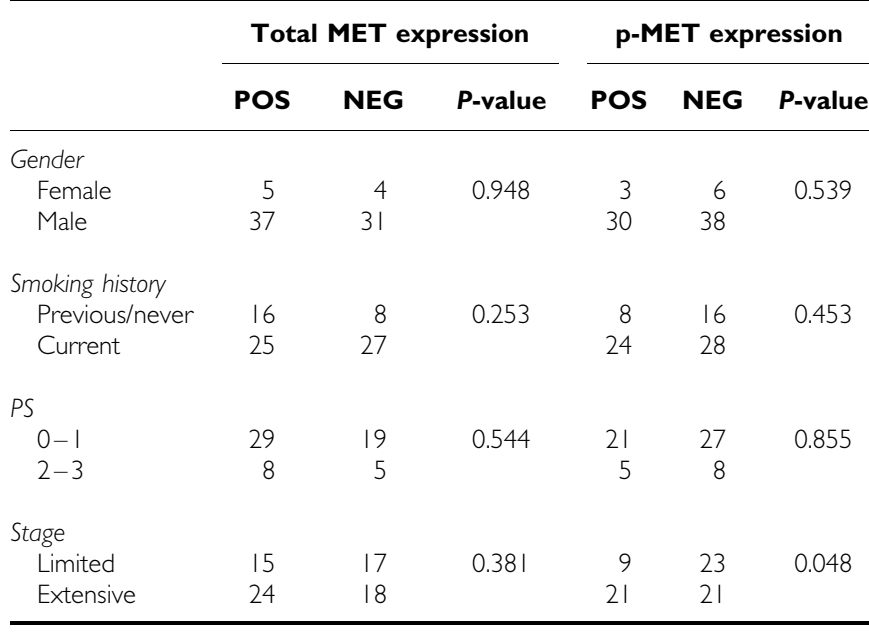

Abbreviations: $\quad N E G=$ negative; $\quad$ P-MET $=$ phosphorylated $\quad M E T ; \quad P O S=$ positive; $\mathrm{PS}=$ performance status.

We next evaluated the association of clinical variables with MET and $\mathrm{p}$-MET status. The only significant association $(P=0.048)$ we found was between p-MET positivity and extensive stage (Table 2).

\section{MET activation is associated with decreased survival in MET-positive SCLC}

To provide data regarding the prognostic impact of MET expression and activation in human SCLC, we performed survival analysis of our series of patients stratified by the status of the markers. We first evaluated the association of clinical variables with overall survival (OS). As expected, patients with limited stage had a significantly better survival than patients with advanced disease $(P<0.001)$. Performance status and gender were not significantly linked to survival in our series in the univariate analysis.

MET expression in SCLC patients was not significantly associated with prognosis (median OS: 270 days in MET overexpression; median OS: 203 days in low/negative MET expression) $(P=0.163)$ (Figure 4).

In contrast, p-MET overexpression in SCLC was significantly associated with a different clinical outcome $(P=0.001)$. Those patients with p-MET overexpression had worse prognosis (OS: 132 days) compared with p-MET negative/low expression cases (OS: 287 days). Moreover, an inverse significant correlation was detected between time of survival and levels of p-MET expression $(P=0.022)$. The range of results for Hscore for $\mathrm{p}$-MET was from 0 to 150 . There was a trend towards an association between higher score and worse outcome $(P=0.091)$. Phospho-MET was assayed with Y1349 in the whole series (Figure 4). Due to lack of sufficient tissue for additional testing in many cases, Y1234/35 was assayed only in 30 specimens. There was a good correlation between the staining with the two antibodies, however, a survival analysis with Y1234/35 was not performed due to reduced number of cases. We performed an additional analysis selecting the 10 cases with highest p-MET expression compared with the rest and observed that median survival was extremely poor in this highest expression group (80.5 days vs 270 days) (Supplementary Figure 3). This suggests the possibility that the level of p-MET expression may influence patient outcome, albeit much larger series would be needed to study this hypothesis.

Finally, in a multivariate analysis including disease stage (the only clinical significant factor in univariate analysis) (Table 3) and
Table 3 Cox multivariate model for overall survival

\begin{tabular}{lcc}
\hline & HR (95\% CI) & P-value \\
\hline Stage (extensive vs limited) & $2.96(1.58-5.54)$ & 0.001 \\
P-MET overexpression (no vs yes) & $1.93(1.07-3.48)$ & 0.028 \\
\hline
\end{tabular}

Abbreviations: $\mathrm{Cl}=$ confidence interval; $\mathrm{HR}=$ hazard ratio.

p-MET status, both parameters remained as independent variables associated with OS $(P<0.05)$.

\section{MET mutations in SCLC}

To explore whether MET mutations and p-MET staining were related, we analysed the previously described $M E T$ mutations in SCLC samples and cell lines: R988C, T1010I and E168C in our specimens. The 37, 20 and 33 samples with enough remaining material were evaluated for each mutation respectively. No mutations were found in these codons, thus precluding the analysis of their potential relationship with p-MET. Of note, however, MET mutations have been described in human SCLC and larger series may allow to analyse this correlation.

\section{DISCUSSION}

Here we demonstrate that MET inhibition, using PHA-665752, is able to counteract HGF-induced effects in MET mutant SCLC cells but not in MET wild-type SCLC cells. The magnitude of the effects was greater in terms of reduced clonogenicity and invasiveness when the inhibitor was used at relatively low concentrations, consistent with those needed to inhibit the target. Furthermore, we provide novel evidence for the activation of MET in about $40 \%$ of patients with SCLC and a link with poor outcome, independent of disease stage.

An intriguing finding was that although $\mathrm{H} 69$ and H69AR harbour a MET mutation, basal levels of phosphorylation were low in both cell lines and only when stimulated with HGF this phosphorylation increased significantly as well as the oncogenic phenotype. Previous studies have suggested that stimulation with HGF is necessary to display the oncogenic properties of cells carrying MET mutations, which is in line with our findings and could be considered an example of oncogene expedience (Michieli et al, 1999; Comoglio et al, 2008). This term has been proposed by Professor Comoglio's group and supports the concept of activation of MET as a secondary event that exacerbates the malignant properties of already transformed cells. In our model MET mutation is not acting as a driver, which may define oncogene addiction but rather as a secondary phenomenon that influences biology of the mutant cell. Our data show that cancer cells with mutant MET (not the wild type) and MET pathway activation via exogenously added HGF have an increased proliferation, invasiveness and colony formation capacity. Some of these effects have been previously described for SCLC cell lines (Maulik et al, 2002; Ma et al, 2003; Jagadeeswaran et al, 2007). Specific inhibition of MET phosphorylation with small molecule inhibitors has demonstrated the capacity of counteracting the HGF induced effects in SCLC and other tumour models (Christensen et al, 2003; Ma et al, 2005; Zou et al, 2007). Here we have not only confirmed these observations but also extended them by providing direct evidence for anti-oncogenic properties of a small molecule inhibitor, PHA665752, in MET mutant SCLC cell lines, independently of their sensitivity/resistance to chemotherapy.

Our work demonstrates that the R988C mutation in our cell line model does not act as a driver mimicking the oncogene addiction phenomenon observed in MET amplified cases (Smolen et al, 2006; Lutterbach et al, 2007). This is in line with a recent work that 
demonstrates lack of functionality of these mutations as oncogenes and are thus considered passenger mutations (Tyner et al, 2010). In our work, the R988C mutation sensitises cells to the effect of HGF and to the effect of the MET inhibitor. This stresses the importance of HGF paracrine/endocrine function in MET mutant tumours that is involved in angiogenesis, growth, migration and invasion (Shojaei et al, 2010) and the potential role of MET inhibitors in cases with MET mutations. There are two studies that report the association between increased HGF serum levels in patients with SCLC and more advanced disease and prognosis (Takigawa et al, 1997; Bharti et al, 2004). However, to our knowledge no study has evaluated the correlation of HGF serum levels and MET expression in SCLC specimens.

There are many studies evaluating the expression of MET but a limited number with p-MET in human tumours and none of them have focused in SCLC (Kuniyasu et al, 1992). Our work demonstrates that MET was expressed in $>70 \%$ of human SCLC, but that p-MET is expressed in $40 \%$ of cases. As expected, MET was also expressed in a high proportion of non-malignant epithelial cells adjacent to malignant tissue. MET expression has been previously reported in non-tumour lung tissue and, in a similar manner of what we report here, specifically a weak expression in the basal aspect of the bronchial epithelium (Olivero et al, 1996; Chen et al, 2006; $\mathrm{Ma}$ et al, 2008). In addition to its physiological role in lung epithelial homeostasis, the MET pathway appears to be critical in the repair of lung damage induced by chronic tobacco exposure (Chen et al, 2006). It is tempting to speculate from this observation that cells with persistent MET activation in the context of tobacco use might be more susceptible to malignant transformation by posterior oncogenic mutations (Pleasance et al, 2009).

From a clinical perspective, the most relevant finding was the prognostic role of p-MET expression in SCLC. As MET phosphorylation is a surrogate marker of receptor activation, this finding is consistent with an adverse role of activated MET receptor in SCLC. This is in agreement with previous reports on the role of p-MET in other tumour types. The prognostic value of p-MET was independent of disease stage, suggesting that it might have a role in the adverse clinical behaviour of patients with this marker. The antibody we used for p-MET expression analysis Y1349 is the epitope of the docking site of MET receptor. Upon HGF binding, MET receptor is activated through dimerisation and phosphorylation of Tyr1234/35 on the catalytic domain. Subsequently phosphorylation of docking sites Tyr1349/56 occurs with recruitment of downstream molecules in our cell line models and has been reported previously (Ponzetto et al, 1994). The connection between both phosphorylation processes and the equivalent results obtained with the Y1234/35 antibody support the role of MET phosphorylation as a negative prognostic marker in this disease.

Secondly and in contrast, total (activation independent) MET expression was not associated with prognosis in our series. In fact, in the literature, the prognostic role of total MET in human cancer is controversial. Albeit many studies point to an adverse prognostic role (Birchmeier et al, 2003; Go et al, 2010; Kim et al,
2010; Liu et al, 2011), other point to the contrary (Furukawa et al, 1995; Belfiore et al, 1997; Nakamura et al, 2007; Cappuzzo et al, 2009; Kanteti et al, 2009). Further studies will be needed to solve this issue.

Heterogeneity in MET expression in whole tissue sections in other tumours has been described (Ma et al, 2007; Benedettini et al, 2010). One of the caveats of our immunohistochemical studies is that they were performed in small biopsies (usual material obtained in this disease) and therefore we could not assess heterogeneity in MET expression in SCLC.

Finally, in order to correlate our preclinical work with our clinical findings we performed mutational studies in cases with available tissue. Due to limited material we were able to study only previously described MET mutations in SCLC in a subset of the whole population. No mutations were found in this sample set. However, MET mutations have been previously described in SCLC specimens (Ma et al, 2003) and although probably infrequent, we believe further studies with larger number of samples are needed to definitively address this area. This is now underway on a prospective project in our institution.

In conclusion, our results add support to the view of MET as an attractive therapeutic target for a subgroup of SCLCs-harbouring $M E T$-activating mutations. They also argue in favour of testing MET targeting agents preferentially in patients whose tumours display p-MET expression or MET mutations.

\section{ACKNOWLEDGEMENTS}

We thank Jorge $\mathrm{R}$ Filho for critical review of the work. We are grateful to Sergi Mojal for assistance in statistical analysis and Trinidad Jiménez, Laura Camacho and Nuria Pérez for technical support. We thank the Tumor Bank of the Department of Pathology of Hospital del Mar and the Xarxa de Bancs de Tumors de Catalunya sponsored by Pla Director d'Oncologia de Catalunya (XBTC) for providing tissue samples and Biobank grants from Instituto de Salud Carlos III FEDER (RD09/0076/00036; RD09/ $0076 / 00101$. We are also grateful to Pfizer for generously providing PHA-665752. This work was partially supported by Plan Nacional de Investigación Científica, Desarrollo e Innovación Tecnológica $(\mathrm{I}+\mathrm{D}+\mathrm{I})$, iniciativa Ingenio 2010, programa Consolider and Instituto de Salud Carlos III (ISCIII)/FEDER (RD06/0020/0109 (IC, MA, FR, EA, JA, AR), RD07/0020/2007(MS)) and PN de I + D + I 2008-20011 and ISCIII/FEDER -Subdirección General de Evaluación y Fomento de la Investigación (PS09/01594 (IC, MA, EA) PS09/01285 (AR, JA) and PS09/01296 (FR). This work was also supported by a grant from DIUE de la Generalitat de Catalunya (2009 SGR 321) (JA, EA, FR, IC, AR, MA). We thank Fundació Cellex (Barcelona) for a generous donation to the Oncology Service (Hospital del Mar); Xarxa de Bancs de tumors).

Supplementary Information accompanies the paper on British Journal of Cancer website (http://www.nature.com/bjc)

\section{REFERENCES}

Arriola E, Canadas I, Arumi M, Rojo F, Rovira A, Albanell J (2008) Genetic changes in small cell lung carcinoma. Clin Transl Oncol 10: 189-197

Baker SG (2003) The central role of receiver operating characteristic (ROC) curves in evaluating tests for the early detection of cancer. J Natl Cancer Inst 95: $511-515$

Bardelli A, Longati P, Gramaglia D, Basilico C, Tamagnone L, Giordano S, Ballinari D, Michieli P, Comoglio PM (1998) Uncoupling signal transducers from oncogenic MET mutants abrogates cell transformation and inhibits invasive growth. Proc Natl Acad Sci USA 95: 14379-14383
Belfiore A, Gangemi P, Costantino A, Russo G, Santonocito GM, Ippolito O, Di Renzo MF, Comoglio P, Fiumara A, Vigneri R (1997) Negative/low expression of the Met/hepatocyte growth factor receptor identifies papillary thyroid carcinomas with high risk of distant metastases. J Clin Endocrinol Metab 82: $2322-2328$

Benedettini E, Sholl LM, Peyton M, Reilly J, Ware C, Davis L, Vena N, Bailey D, Yeap BY, Fiorentino M, Ligon AH, Pan BS, Richon V, Minna JD, Gazdar AF, Draetta G, Bosari S, Chirieac LR, Lutterbach B, Loda M (2010) Met activation in non-small cell lung cancer is associated with 
de novo resistance to EGFR inhibitors and the development of brain metastasis. Am J Pathol 177: 415-423

Bharti A, Ma PC, Maulik G, Singh R, Khan E, Skarin AT, Salgia R (2004) Haptoglobin alpha-subunit and hepatocyte growth factor can potentially serve as serum tumor biomarkers in small cell lung cancer. Anticancer Res 24: $1031-1038$

Birchmeier C, Birchmeier W, Gherardi E, Vande Woude GF (2003) Met, metastasis, motility and more. Nat Rev Mol Cell Biol 4: 915-925

Cappuzzo F, Janne PA, Skokan M, Finocchiaro G, Rossi E, Ligorio C, Zucali PA, Terracciano L, Toschi L, Roncalli M, Destro A, Incarbone M, Alloisio M, Santoro A, Varella-Garcia M (2009) MET increased gene copy number and primary resistance to gefitinib therapy in non-small-cell lung cancer patients. Ann Oncol 20: 298-304

Codony-Servat J, Tapia MA, Bosch M, Oliva C, Domingo-Domenech J, Mellado B, Rolfe M, Ross JS, Gascon P, Rovira A, Albanell J (2006) Differential cellular and molecular effects of bortezomib, a proteasome inhibitor, in human breast cancer cells. Mol Cancer Ther 5: 665-675

Comoglio PM, Giordano S, Trusolino L (2008) Drug development of MET inhibitors: targeting oncogene addiction and expedience. Nat Rev Drug Discov 7: $504-516$

Comoglio PM, Trusolino L (2002) Invasive growth: from development to metastasis. J Clin Invest 109: 857 - 862

Cooper S, Spiro SG (2006) Small cell lung cancer: treatment review. Respirology 11: $241-248$

Corso S, Migliore C, Ghiso E, De Rosa G, Comoglio PM, Giordano S (2008) Silencing the MET oncogene leads to regression of experimental tumors and metastases. Oncogene 27: 684-693

Chen JT, Lin TS, Chow KC, Huang HH, Chiou SH, Chiang SF, Chen HC, Chuang TL, Lin TY, Chen CY (2006) Cigarette smoking induces overexpression of hepatocyte growth factor in type II pneumocytes and lung cancer cells. Am J Respir Cell Mol Biol 34: 264-273

Cheng S, Evans WK, Stys-Norman D, Shepherd FA (2007) Chemotherapy for relapsed small cell lung cancer: a systematic review and practice guideline. $J$ Thorac Oncol 2: 348-354

Christensen JG, Schreck R, Burrows J, Kuruganti P, Chan E, Le P, Chen J, Wang X, Ruslim L, Blake R, Lipson KE, Ramphal J, Do S, Cui JJ, Cherrington JM, Mendel DB (2003) A selective small molecule inhibitor of c-Met kinase inhibits c-Met-dependent phenotypes in vitro and exhibits cytoreductive antitumor activity in vivo. Cancer Res 63: $7345-7355$

Danilkovitch-Miagkova A, Zbar B (2002) Dysregulation of Met receptor tyrosine kinase activity in invasive tumors. J Clin Invest 109: 863-867

Engelman JA, Zejnullahu K, Mitsudomi T, Song Y, Hyland C, Park JO, Lindeman N, Gale CM, Zhao X, Christensen J, Kosaka T, Holmes AJ, Rogers AM, Cappuzzo F, Mok T, Lee C, Johnson BE, Cantley LC, Janne PA (2007) MET amplification leads to gefitinib resistance in lung cancer by activating ERBB3 signaling. Science 316: 1039-1043

Furge KA, Zhang YW, Vande Woude GF (2000) Met receptor tyrosine kinase: enhanced signaling through adapter proteins. Oncogene 19: $5582-5589$

Furukawa T, Duguid WP, Kobari M, Matsuno S, Tsao MS (1995) Hepatocyte growth factor and Met receptor expression in human pancreatic carcinogenesis. Am J Pathol 147: 889-895

Gaudino G, Follenzi A, Naldini L, Collesi C, Santoro M, Gallo KA, Godowski PJ, Comoglio PM (1994) RON is a heterodimeric tyrosine kinase receptor activated by the HGF homologue MSP. EMBO J 13: 3524-3532

Giordano S, Ponzetto C, Di Renzo MF, Cooper CS, Comoglio PM (1989) Tyrosine kinase receptor indistinguishable from the c-met protein. Nature 339: $155-156$

Go H, Jeon YK, Park HJ, Sung SW, Seo JW, Chung DH (2010) High MET gene copy number leads to shorter survival in patients with non-small cell lung cancer. $J$ Thorac Oncol 5: 305-313

Govindan R, Page N, Morgensztern D, Read W, Tierney R, Vlahiotis A, Spitznagel EL, Piccirillo J (2006) Changing epidemiology of small-cell lung cancer in the United States over the last 30 years: analysis of the surveillance, epidemiologic, and end results database. J Clin Oncol 24: $4539-4544$

Jagadeeswaran R, Jagadeeswaran S, Bindokas VP, Salgia R (2007) Activation of HGF/c-Met pathway contributes to the reactive oxygen species generation and motility of small cell lung cancer cells. Am J Physiol Lung Cell Mol Physiol 292: L1488-L1494

Kanteti R, Yala S, Ferguson MK, Salgia R (2009) MET, HGF, EGFR, and PXN gene copy number in lung cancer using DNA extracts from FFPE archival samples and prognostic significance. J Environ Pathol Toxicol Oncol 28: 89-98
Kim CH, Koh YW, Han JH, Kim JW, Lee JS, Baek SJ, Hwang HS, Choi EC (2010) c-Met expression as an indicator of survival outcome in patients with oral tongue carcinoma. Head Neck 32: 1655-1664

Kong-Beltran M, Seshagiri S, Zha J, Zhu W, Bhawe K, Mendoza N, Holcomb T, Pujara K, Stinson J, Fu L, Severin C, Rangell L, Schwall R, Amler L, Wickramasinghe D, Yauch R (2006) Somatic mutations lead to an oncogenic deletion of met in lung cancer. Cancer Res 66: 283-289

Kuniyasu H, Yasui W, Kitadai Y, Yokozaki H, Ito H, Tahara E (1992) Frequent amplification of the c-met gene in scirrhous type stomach cancer. Biochem Biophys Res Commun 189: 227-232

Liu W, Fu Y, Xu S, Ding F, Zhao G, Zhang K, Du C, Pang B, Pang Q (2011) c-Met expression is associated with time to recurrence in patients with glioblastoma multiforme. J Clin Neurosci 18: 119-121

Lutterbach B, Zeng Q, Davis LJ, Hatch H, Hang G, Kohl NE, Gibbs JB, Pan BS (2007) Lung cancer cell lines harboring MET gene amplification are dependent on Met for growth and survival. Cancer Res 67: 2081-2088

Ma PC, Kijima T, Maulik G, Fox EA, Sattler M, Griffin JD, Johnson BE, Salgia R (2003) c-MET mutational analysis in small cell lung cancer: novel juxtamembrane domain mutations regulating cytoskeletal functions. Cancer Res 63: 6272-6281

Ma PC, Schaefer E, Christensen JG, Salgia R (2005) A selective small molecule c-MET Inhibitor, PHA665752, cooperates with rapamycin. Clin Cancer Res 11: 2312-2319

Ma PC, Tretiakova MS, MacKinnon AC, Ramnath N, Johnson C, Dietrich S, Seiwert T, Christensen JG, Jagadeeswaran R, Krausz T, Vokes EE, Husain AN, Salgia R (2008) Expression and mutational analysis of MET in human solid cancers. Genes Chromosomes Cancer 47: 1025-1037

Ma PC, Tretiakova MS, Nallasura V, Jagadeeswaran R, Husain AN, Salgia R (2007) Downstream signalling and specific inhibition of c-MET/HGF pathway in small cell lung cancer: implications for tumour invasion. $\mathrm{Br} J$ Cancer 97: $368-377$

Maulik G, Kijima T, Ma PC, Ghosh SK, Lin J, Shapiro GI, Schaefer E, Tibaldi E, Johnson BE, Salgia R (2002) Modulation of the c-Met/ hepatocyte growth factor pathway in small cell lung cancer. Clin Cancer Res 8: $620-627$

McShane LM, Altman DG, Sauerbrei W, Taube SE, Gion M, Clark GM (2005) REporting recommendations for tumour MARKer prognostic studies (REMARK). Br J Cancer 93: 387-391

Michieli P, Basilico C, Pennacchietti S, Maffe A, Tamagnone L, Giordano S, Bardelli A, Comoglio PM (1999) Mutant Met-mediated transformation is ligand-dependent and can be inhibited by HGF antagonists. Oncogene 18: $5221-5231$

Nakamura Y, Niki T, Goto A, Morikawa T, Miyazawa K, Nakajima J, Fukayama M (2007) c-Met activation in lung adenocarcinoma tissues: an immunohistochemical analysis. Cancer Sci 98: 1006-1013

Naldini L, Weidner KM, Vigna E, Gaudino G, Bardelli A, Ponzetto C, Narsimhan RP, Hartmann G, Zarnegar R, Michalopoulos GK, Birchmeier W, Comoglio PM (1991) Scatter factor and hepatocyte growth factor are indistinguishable ligands for the MET receptor. EMBO J 10: 2867-2878

Olivero M, Rizzo M, Madeddu R, Casadio C, Pennacchietti S, Nicotra MR, Prat M, Maggi G, Arena N, Natali PG, Comoglio PM, Di Renzo MF (1996) Overexpression and activation of hepatocyte growth factor/scatter factor in human non-small-cell lung carcinomas. $\mathrm{Br} J$ Cancer 74: $1862-1868$

Park M, Dean M, Kaul K, Braun MJ, Gonda MA, Vande Woude G (1987) Sequence of MET protooncogene CDNA has features characteristic of the tyrosine kinase family of growth-factor receptors. Proc Natl Acad Sci USA 84: 6379-6383

Peschard P, Fournier TM, Lamorte L, Naujokas MA, Band H, Langdon WY, Park M (2001) Mutation of the c-Cbl TKB domain binding site on the Met receptor tyrosine kinase converts it into a transforming protein. $\mathrm{Mol}$ Cell 8: $995-1004$

Pleasance ED, Stephens PJ, O'Meara S, McBride DJ, Meynert A, Jones D, Lin ML, Beare D, Lau KW, Greenman C, Varela I, Nik-Zainal S, Davies HR, Ordonez GR, Mudie LJ, Latimer C, Edkins S, Stebbings L, Chen L, Jia M, Leroy C, Marshall J, Menzies A, Butler A, Teague JW, Mangion J, Sun YA, McLaughlin SF, Peckham HE, Tsung EF, Costa GL, Lee CC, Minna JD, Gazdar A, Birney E, Rhodes MD, McKernan KJ, Stratton MR, Futreal PA, Campbell PJ (2009) A small-cell lung cancer genome with complex signatures of tobacco exposure. Nature 463: $184-190$

Ponzetto C, Bardelli A, Zhen Z, Maina F, dalla Zonca P, Giordano S, Graziani A, Panayotou G, Comoglio PM (1994) A multifunctional docking site mediates signaling and transformation by the hepatocyte growth factor/scatter factor receptor family. Cell 77: 261-271 
Puri N, Ahmed S, Janamanchi V, Tretiakova M, Zumba O, Krausz T, Jagadeeswaran R, Salgia R (2007) c-Met is a potentially new therapeutic target for treatment of human melanoma. Clin Cancer Res 13: 2246-2253

Qian CN, Guo X, Cao B, Kort EJ, Lee CC, Chen J, Wang LM, Mai WY, Min HQ, Hong MH, Vande Woude GF, Resau JH, Teh BT (2002) Met protein expression level correlates with survival in patients with late-stage nasopharyngeal carcinoma. Cancer Res 62: 589-596

Rosen EM, Nigam SK, Goldberg ID (1994) Scatter factor and the c-met receptor: a paradigm for mesenchymal/epithelial interaction. J Cell Biol 127: 1783 - 1787

Sachs M, Brohmann H, Zechner D, Muller T, Hulsken J, Walther I, Schaeper U, Birchmeier C, Birchmeier W (2000) Essential role of Gab1 for signaling by the c-Met receptor in vivo. J Cell Biol 150: 1375-1384

Salido M, Arriola E, Carracedo A, Canadas I, Rovira A, Espinet B, Rojo F, Arumi M, Serrano S, Albanell J, Sole F (2009) Cytogenetic characterization of NCI-H69 and NCI-H69AR small cell lung cancer cell lines by spectral karyotyping. Cancer Genet Cytogenet 191: 97-101

Sattler M, Pride YB, Ma P, Gramlich JL, Chu SC, Quinnan LA, Shirazian S, Liang C, Podar K, Christensen JG, Salgia R (2003) A novel small molecule met inhibitor induces apoptosis in cells transformed by the oncogenic TPR-MET tyrosine kinase. Cancer Res 63: 5462 - 5469

Schiller JH, Akerley WL, Brugger W, Ferrari D, Garmey EG, Gerber DE, Orlov SV, Ramlau R, Von Pawel J, Sequist LV (2010) Results from ARQ 197-209: A Global Randomized Placebo-Controlled Phase II Clinical Trial of Erlotinib Plus ARQ 197 versus Erlotinib Plus Placebo in Previously Treated EGFR Inhibitor-Naive Patients with Locally Advanced or Metastatic Non-Small Cell Lung Cancer (NSCLC). ASCO: Chicago

Shojaei F, Lee JH, Simmons BH, Wong A, Esparza CO, Plumlee PA, Feng J, Stewart AE, Hu-Lowe DD, Christensen JG (2010) HGF/c-Met acts as an alternative angiogenic pathway in sunitinib-resistant tumors. Cancer Res 70: $10090-10100$
Smolen GA, Sordella R, Muir B, Mohapatra G, Barmettler A, Archibald H, Kim WJ, Okimoto RA, Bell DW, Sgroi DC, Christensen JG, Settleman J, Haber DA (2006) Amplification of MET may identify a subset of cancers with extreme sensitivity to the selective tyrosine kinase inhibitor PHA665752. Proc Natl Acad Sci USA 103: 2316-2321

Spigel D, Ervin T, Ramlau R, Daniel D, Goldschmidt J, Krzakowski M, Godbert B, Yu W, Patel PH, Peterson A (2010) Randomized Multicenter Double-Blind Placebo Controlled Phase II Study Evaluating METMab, an Antibody to MET Receptor, in Combination with erlotinib, in Patients with Advanced Non-Small Cell Lung Cancer. ESMO: Milan

Spira A, Ettinger DS (2004) Multidisciplinary management of lung cancer. N Engl J Med 350: 379-392

Takigawa N, Segawa Y, Maeda Y, Takata I, Fujimoto N (1997) Serum hepatocyte growth factor/scatter factor levels in small cell lung cancer patients. Lung Cancer 17: 211-218

Tuynman JB, Lagarde SM, Ten Kate FJ, Richel DJ, van Lanschot JJ (2008) Met expression is an independent prognostic risk factor in patients with oesophageal adenocarcinoma. Br J Cancer 98: 1102-1108

Tyner JW, Fletcher LB, Wang EQ, Yang WF, Rutenberg-Schoenberg ML, Beadling C, Mori M, Heinrich MC, Deininger MW, Druker BJ, Loriaux MM (2010) MET receptor sequence variants R970C and T992I lack transforming capacity. Cancer Res 70: 6233-6237

Weidner KM, Di Cesare S, Sachs M, Brinkmann V, Behrens J, Birchmeier W (1996) Interaction between Gabl and the c-Met receptor tyrosine kinase is responsible for epithelial morphogenesis. Nature 384: 173-176

Zou HY, Li Q, Lee JH, Arango ME, McDonnell SR, Yamazaki S, Koudriakova TB, Alton G, Cui JJ, Kung PP, Nambu MD, Los G, Bender SL, Mroczkowski B, Christensen JG (2007) An orally available small-molecule inhibitor of c-Met, PF-2341066, exhibits cytoreductive antitumor efficacy through antiproliferative and antiangiogenic mechanisms. Cancer Res 67: 4408-4417

This work is published under the standard license to publish agreement. After 12 months the work will become freely available and the license terms will switch to a Creative Commons Attribution-NonCommercial-Share Alike 3.0 Unported License. 